\title{
"Repressive Measures"
}

\begin{abstract}
A.J. Andrews, the Committee of 1000 and the Campaign Against Radicalism After the Winnipeg General Strike
\end{abstract}

\section{Tom Mitchell}

He who establishes a dictatorship and does not kill Brutus, or he who founds a republic and does not kill the sons of Brutus, will only reign a short time. (Machiavelli: Discorsi) ${ }^{1}$

In the late spring of 1919, 35000 unionized and non-unionized workers in the city of Winnipeg walked off the job in support of demands by workers in the city's building and metal trades for collective bargaining rights. From 14 May to 25 June 1919 the commercial and industrial life of the city was effectively shut down. At the same time, sympathetic strikes spread to communities small and large across the country. These events were rooted in the

1 As quoted in Arthur Koestler, Darkness at Noon (London 1940), 9. The reference to "repressive measures" in the title is taken from A.J. Andrews to Arthur Meighen, 18 Jul. 1919, National Archives of Canada (NAC), Records of the Department of Justice, RG 13, Access 1987-88/103, Box 36, file A-1688, "Winnipeg General Strike" (Pocket 2) (Hereafter NAC, Access, "Winnipeg" Justice). 
opposition of the country's workers to a return to pre-war relations of power and authority in a reconstructed Canada. ${ }^{2}$ Defenders of the old order seized on the labour revolt of 1919 as a pernicious challenge to the existing order. The Winnipeg business elite, organized as the Committee of 1000, sought to mobilize elements of civil society and the state against the strike. The strike's opponents in Winnipeg and elsewhere were convinced that the general strike weapon, successfully deployed, would undermine the property rights of capital and enfeeble the authority of the state. The strike could not be allowed to succeed.

Ironically, Canadian historians have been generally reluctant to explore the complex ontology of the 1919 labour revolt. ${ }^{3}$ As James Naylor has explained, most accounts "fit [the Winnipeg strike] into a whiggish narrative of the expansion of a modern industrial relations regime with free collective bargaining." writer has argued that "to seek hidden inner meanings to this event, rather than to study it for what it was, is to impart to it more than anyone has the right to." Yet thoughtful contemporary observers were not reluctant to describe the pathology afflicting Canadian society. Nor did they lack for meanings to ascribe to the post-war maelstrom. ${ }^{6}$ For their part, the Winnipeg strike's opponents were

2 Gregory Kealey, "1919: The Canadian Labour Revolt," Labour/Le Travail, 13 (1984), 11-44.

3 The standard accounts of the strike are D.C. Masters, The Winnipeg General Strike (Toronto 1973); Kenneth McNaught and David J. Bercuson, The Winnipeg General Strike: 1919 (Don Mills 1974); David Jay Bercuson, Confrontation in Winnipeg: Labour, Industrial Relations, and the General Strike (Montreal 1974); and J.M. Bumsted, The Winnipeg General Strike of 1919: An Illustrated History (Winnipeg 1994).

4 James Naylor, "'Strike or Revolution?' The Labour Revolt of 1919 and the Winnipeg General Strike," Paper presented to the 29th Annual Northern Great Plains History Conference, St. Paul, 29 Sept. 1994, 1.

5 David Jay Bercuson, Confrontation in Winnipeg (Kingston 1990), 270.

6 See O.D. Skelton who believed that the war had "produced a reckless and desperate temper" and that "acquiescence in the established order" was a thing of the past.(O.D. Skelton, "Current Events," Queen's Quarterly, Jul. - Sept. 1919). W.L. Grant concluded that since 1914 the old order had been discredited and that post-war society had to be rooted in "something deeper and more spiritual" than laissez-faire individualism.(W.L. Grant, 
convinced that the strike and the agitation that followed it were products of a conspiracy designed to transform pervasive post-war disaffection with the social order into revolution. In August 1919, Sir James Aikens K.C., Lieutenant Governor of Manitoba, told the Canadian Bar Association meeting in Winnipeg that the post-war crisis represented the return of an age old disorder: "Bolshevism ... was a recrudescence of an old disease, a frequent consequence of war."7

Aikens perspective reflected the settled view of the Winnipeg business and legal communities on post-war radicalism. Organized under the banner of the Citizens' Committee of 1000 from 19 May 1919, Winnipeg's business elite was the principal bulwark against the strike. Drawn principally from the Board of Trade and the Winnipeg branch of the Manufacturer's Association, the Committee also included several prominent members of the Winnipeg legal community including A.J. Andrews, Isaac Pitblado, Travers Sweatman, and J.C. Coyne. ${ }^{8}$ Andrews, a founding member, was the principal architect of the suppression of the strike following his

"The Education of the Working Man," Queen's Quarterly, Oct. - Dec., 1919); G.S. Brett sought the meaning of 1919 in a consideration of man's tendency to irrationalism. See G.S. Brett, "The Revolt Against Reason: A Contribution to the History of Thought," in Transactions of the Royal Society of Canada, series 3, Vol. 13, 1919; Robert Falconer was convinced that Canadian society was in a "diseased condition." See Robert Falconer's conference address in the Report of the Proceedings of the National Conference on Character Education in Relation to Canadian Citizenship (Winnipeg 1919), 25-26. For an international perspective see The Right Hon. Arthur Henderson, "The Industrial Unrest: A New Policy Required," The Contemporary Review, Vol. CXV (Jan.-Jun. 1919). See also Barry Ferguson, Remaking Liberalism (Montreal \& Kingston 1993), 217-8 and Douglas Owram, The Government Generation: Canadian Intellectuals and the State, 1900 - 1945 (Toronto 1986), 80.

7 Proceedings of the Fourth Annual Meeting of the Canadian Bar Association (Winnipeg 1920), 85.

8 In the early twentieth century the legal profession in Western Canada had come to embrace a professionalism preoccupied with containment of discontent and maintenance of order. See W. Wesley Pue, "A Profession In Defence of Capital?" Canadian Journal of Law and Society, 7, 2 (Fall 1992), 267-84. 
appointment by Arthur Meighen to advise Ottawa on how to defeat the strike. ${ }^{9}$ Like Aikins, Andrews and his associates in the Committee of 1000 did not believe that the defeat of the strike ended the threat to authority. The Citizens were convinced that labour radicalism was at the root of a persistent and deepening crisis that was a threat, more profound than the strike, to the stability of the social order. $^{10}$

Insistent on portraying the Winnipeg strike as a straight forward industrial relations conflict, historians have complacently dismissed or ignored developments following in its wake. This tendency is consistent with the construction of the strike as a limited war of position on the terrain of industrial relations. Yet such an approach ignores the rich complexity of the strike and its aftermath as principal features of the moral and political malaise that afflicted post-war Canada and threatened the hegemony of the Canadian business class.

This paper examines the successful campaign of Andrews and the Citizens' Committee to enlist the authority and resources of the federal Department of Justice in legal and ideological assaults on labour radicalism after the strike. While these assaults represent the denouement of the May-June struggle in Winnipeg, they had a national focus and were designed to discredit and disperse proponents of labour radicalism in Winnipeg and elsewhere and to restore the legitimacy of the existing order. Ironically, Arthur

9 A member of the Winnipeg elite throughout his career, Andrews was "respected and feared but never hated by his opponents." Roy St. Stubbs, Prairie Portraits (Toronto 1954), 54. For a description of the role of A.J. Andrews in the suppression of the strike see Tom Mitchell, "'To Reach the Leaders of this Revolutionary Movement': A.J. Andrews, the Canadian State, and the Suppression of the Winnipeg General Strike," Prairie Forum, 18, 3 (Fall 1993), 239-255.

10 On the origin and membership of the Citizens' Committee of 1000 see D.C. Masters, The Winnipeg General Strike, 63-8. British Intelligence took an interest in the counter-revolutionary potential of the Committee of 1000 . See Gregory S. Kealey, "The RCMP, the Special Branch, and the Early Days of the Communist Party in Canada: A Documentary Article," Labour/Le Travail, 30 (Fall 1992), 170. 
Meighen, who served as acting Minister of Justice until the Minister, C.J. Doherty, returned in late July 1919, repeatedly rejected demands from Andrews and other leading members of the Committee for Department of Justice sponsorship of this campaign. ${ }^{11}$ Upon his return, Doherty abandoned Meighen's position and wedded the Department of Justice to the Citizen's project of repression.

An examination of these developments, culminating in the sedition proceedings in Winnipeg in the fall and winter of 1919 and 1920 , discloses the nature of the continuing struggle between capital and labour on the terrain of politics and the law in the wake of the strike. In this struggle, the Winnipeg business and legal elites, not the workers, were the real historical protagonists. They set the agenda of conflict, determined the terrain and rules of engagement, and massed the resources of the state in a relentless war of position against labour radicalism. Yet, contrary to the general portrayal of the strike's aftermath as a period of abject defeat for labour, the response of workers to the Citizens' campaign was one of struggle and resistance.

From the outset of the strike, the Citizen's Committee had noisily called for the arrest of the strike leadership. On the night of 17 June 1919, this was accomplished when the strike leadership was taken into custody and held, on Andrews' initiative, under provisions of both the Criminal Code and the only recently amended Immigration Act. In the days that followed, Andrews began the laborious process of examining the mass of material collected by Royal North West Mounted Police (RNWMP) in raids in Winnipeg on 17 June 1919 and in others across the country in late June, and to engage counsel, including Committee of 1000 executive committee members Isaac Pitblado, Travers Sweatman, and J.C. Coyne. ${ }^{12}$

11 On Meighen's career see Roger Graham, Arthur Meighen: The Door of Opportunity (Toronto 1960).

12 A.J. Andrews to Arthur Meighen, 2 Jul. 1919, NAC, Access, "Winnipeg" Justice, (Pocket 2). See as well, Andrews to Meighen, 18 June 1919, NAC, Access, "Winnipeg" Justice, (Pocket 2). D.C. Masters reports that all were 
In early July, Andrews told Meighen that Hugh Phillips, K.C., who had been retained by the province to deal with cases arising from the General Strike, had asked that federal authorities undertake the prosecution of J.S. Woodsworth and Fred Dixon, arrested on 25 June 1919 for their efforts in publishing the Western Labour News. ${ }^{13}$ Andrews supported the request. He believed that the country could not "afford on the score of economy to neglect any legitimate means of bringing to light the true situation as it exists in Canada." 14 Meighen disagreed. He told Andrews that, as Woodsworth and Dixon had been arrested on instructions of provincial authorities, and as the duty for such prosecutions was a provincial one, he could see no reason why the federal government should take the cases. ${ }^{15}$

Clearly taken by surprise, Andrews implored Meighen to direct him to proceed with the cases for "prosecution should follow to justify these raids." 16 He reiterated his position on 10 July 1919 asserting that evidence existed to prove that there was an active, persistent and effective campaign being carried on in favour of Bolshevism. Prosecutions and vigorous action on the part of government would cause "fear and confusion in the ranks of the

"extremely active" in the Committee of 1000. D.C. Masters, The Winnipeg General Strike, 64.

13 A.J. Andrews to Arthur Meighen, 3 Jul. 1919, NAC, Access, "Winnipeg" Justice, (Pocket 2). For Phillips recollection of his role in the Strike see Winnipeg Tribune, 6 April 1949. Andrews included J.A. Martin, and James Grant with Woodsworth and Dixon. Martin and Grant never faced trial as the Grand Jury of the Eastern Judicial District declined to return true bills against them for allegedly having spoken seditious words. Winnipeg Evening Tribune, 25 Nov. 1919. In January and February 1920 Fred Dixon, after defending himself, was acquitted of charges of seditious libel. In light of the decision in the Dixon case, the Crown chose to drop its case against Woodsworth. See D.C. Masters, The Winnipeg General Strike, 124-6.

14 A.J. Andrews to Meighen, 2 Jul. 1919, NAC, Access, "Winnipeg" Justice, (Pocket 2).

15 Arthur Meighen to A.J. Andrews,4 Jul 1919, NAC, Access, "Winnipeg" Justice, (Pocket 2). Meighen had expressed similar views in the Commons. See Debates of the House of Commons, Vol. IV, 1919, 3845-6.

16 A.J. Andrews to Arthur Meighen, 7 Jul. 1919, NAC, Access, "Winnipeg" Justice, (Pocket 2). 
revolutionists." Yet, Andrews explained, the Government appeared to believe that "repression and suppression tend[ed] to flame rather than destroy revolutionary tendencies." Andrews and what he termed his "associate council" were unanimous in the view that "the only way to deal with Bolshevism is to hit it and to hit it hard, every time it lifts its ugly head." threatening that if the prosecution of the arrested strike leaders and others was dropped not only would there be a gross failure in the administration of the law, "but ... your government will be blamed as much as the local government.",18

The Manitoba government had no appetite for criminal prosecutions of the strike leaders. The Norris government was eager to see an end to social strife. Elected by a rural populace almost certain to be unenthusiastic about an expensive prosecution at a time of rural economic distress, it was largely immune to pressure from the Citizens' Committee to proceed with prosecutions arising from the strike. ${ }^{19}$ Manitoba's disinterest, combined with Meighen's rejection of Andrews' demand for federal sponsorship, made any prosecution increasingly problematic. On 3 July 1919, when the strike leaders appeared in court, ostensibly for a preliminary hearing on the charges against them, their cases were remanded at Andrews' request. $^{20}$

At the same time, agitation continued against any criminal prosecution or summary deportation of the Winnipeg strike leaders. Across the country individuals, labour councils, women's

17 A.J. Andrews to Arthur Meighen, 10 Jul. 1919, NAC, Access, "Winnipeg" Justice, (Pocket 2).

18 Ibid.

19 On the Norris government's role in the Strike see W.L. Morton, Manitoba: A History (Toronto 1957), 368-73.

20 Those remanded included R.B.Russell, William Ivens, W.A. Pritchard, John Queen, A.A. Heaps, George Armstrong, R.E. Bray, R.J. Johns, Sam Blumenberg, Oscar Schoppelrei, Moses Almazoff, Max Charitonoff, and Mike Verenczuk. The latter five were transferred from Stoney Mountain Penitentiary to the Winnipeg Immigration Hall pending their hearing under the Immigration Act. The others were freed on bail. Winnipeg Free Press, 4 Jul. 1919, 5 . 
labour leagues, and informally organized groups of workers petitioned the Department of Justice for "British justice" for the arrested men. ${ }^{21}$ As well "defence committees" were organized to raise funds in support of the strike leaders and to campaign for their release. In a speech to an open air rally in Winnipeg's Market Square on 9 July 1919, F.J. Dixon asserted that "the Canadian people were in the process of having their rights and liberties stolen from them by the shabbiest pack of political jackals that ever harassed a civilized country." 22

On 11 July 1919, consideration of the criminal charges was postponed again at Andrews' request. He told the court that he had not had adequate time to examine the mass of evidence gathered against the accused. ${ }^{23}$ In fact, Andrews' incapacity was rooted in the refusal of the federal Department of Justice to sponsor prosecutions from which the Province of Manitoba had for all practical purposes withdrawn. On 12 July Andrews told Meighen that provincial authorities had finally decided not to proceed with prosecution of any of the sedition cases. ${ }^{24} \mathrm{He}$ pressed for permission to intervene. He was told "not to do so." 25 Yet, Andrews would not relent. He told Meighen that reports from the Secret Service indicated an increasingly active propaganda in favour of "revolution." Moreover, all who were engaged in preparing for the prosecution believed that "repressive measures confuse and defeat the ends of

21 For a discussion of the use by workers of public protest, petitions, letters to protest the detention and trial of the strike leaders see James Muir, "The Demand For British Justice: Protest and Culture During the Winnipeg General Strike Trials," unpublished paper, University of Manitoba Canadian Legal History Project. For a list of the letters and petitions both supporting and opposing the detention and trial of the strike leaders see Ken Kehler and Alvin Esau, Famous Manitoba Trials: The Winnipeg General Strike Trials Research Source (Winnipeg 1990), 73-85. These actual petitions and letters are contained in NAC, Access, "Winnipeg" Justice, (Pocket 1).

22 Winnipeg Free Press, 10 Jul. 1919, 5.

23 Ibid.,12 Jul. 1919.

24 A.J. Andrews to Arthur Meighen, 12 Jul 1919, NAC, Access, "Winnipeg" Justice, (Pocket 2).

25 Arthur Meighen to A.J. Andrews, 14 Jul. 1919 and 17 Jul. 1919, NAC, Access, "Winnipeg" Justice, (Pocket 2). 
agitators," while inaction by the state contributed to the effectiveness of radical propaganda. ${ }^{26}$ If Meighen refused to act, he expected that the " the Citizens' Committee would instruct private counsel to carry on the prosecution of these cases."27

Some writers have argued that, following the Winnipeg strike, A.J. Andrews "was a restraining influence ... upon extremists, like Meighen, in the cabinet." ${ }^{28}$ Such a reading of Meighen's role in the developments following the arrest of the strike leaders and the suppression of the strike is fundamentally wrong. In fact, Andrews and his associates in the Committee of 1000 were the "extremists" determined to mobilize the federal state in an active offensive against labour radicalism. It was Meighen who rejected their claims at every turn and dismissed their grim warnings of impending social disorder. ${ }^{29} \mathrm{He}$ was resolute that the special circumstances that had warranted an extraordinary intervention of the federal state in the lives of Canadians had ended with the conclusion of the war. ${ }^{30}$ On 26 June 1919 Robert Borden had explained to a caucus

26 A.J. Andrews to Arthur Meighen, 18 July 1919, NAC, Access, "Winnipeg" Justice, (Pocket 2).

27 A.J. Andrews to Arthur Meighen, 18 Jul. 1919, NAC, Access, "Winnipeg" Justice, (Pocket 2). The convention that the state would act as the principal prosecutor of the criminal law is a relatively recent convention. Douglas Hay makes the point that "private prosecution was carefully protected until the recent past, and that it was thought an important constitutional guarantee of civil liberty." He quotes Sir James Stephen, writing in 1883, that private prosecutions "both in our days and earlier times, have given a legal vent to feelings every way entitled to respect, and have decided peaceably and in an authentic manner many questions of great constitutional importance." For both quotes see Douglas Hay, "Controlling the English Prosecutor," Osgoode Hall Law Journal, 21, 2 (June 1983), 166-7.

28 McNaught and Bercuson, The Winnipeg General Strike: 1919, 81.

29 In a wire to Andrews dated $17 \mathrm{Jul}$. 1919 Meighen told Andrews that "Council takes ground that Federal Government cannot undertake prosecutions have everywhere until now been entered and conducted by Provincial authority." NAC, Access, "Winnipeg" Justice, (Pocket 2).

30 See Gregory S. Kealey, "State Repression of Labour and the Left in Canada, 1914-1920: The Impact of the First World War," Canadian Historical Review, 73 (Sept. 1992), 281-314, for an examination of the activities of the Canadian state in suppressing radicalism and defending Canadian capitalism during and immediately after the Great War. 
meeting of Union supporters that to secure a mandate from the country three policies, among others, were essential to success: upholding constitutional authority at the federal, provincial and municipal level; abandoning repressive and restrictive measures necessitated by the war; and recognizing the "legitimate and reasonable" aspirations of organized labour. ${ }^{31}$ Meighen's rejection of Andrews' call to arms was consistent with Borden's design for a return to normalcy.

For similar reasons, Meighen was also unwilling to bend to the Committee of 1000's determination to employ Orders in Council approved under the War Measures Act to prosecute those found in possession of prohibited literature. On 17 July 1919 Andrews had wired Meighen to urge prosecution of persons found with prohibited matter. Andrews sought authority to proceed under Section 7, Order 2, of the Consolidated Orders in Council. He told Meighen that Pitblado, Coyne and others supported the idea and that Commissioner Perry of the RNWMP had assumed that prosecutions under the Consolidated Orders would follow the raids at the end of June. Andrews explained that the benefits of the raids would be lost if no action was taken against those in possession of prohibited publications. Moreover prosecutions "would be ample justification for the making of the raids.",32

Andrews had wired for special instructions from Meighen because, under the Consolidated Censor Orders, if the prosecution was initiated on instructions from the Minister, the information itself, explained Andrews, was "prima facie proof of all facts alleged therein and would save a great deal of expense and difficulty in securing convictions." ${ }^{33}$ Ernest Chambers, chief press censor for the Borden government from June 1915 to 1 January

31 Robert Laird Borden, His Memoirs, Vol. II (Toronto 1969), 220. On this general theme see as well James Naylor, "Workers and the State: Experiments in Corporatism After World War One," Studies in Political Economy, 42 (Autumn 1993), 95-6.

32 A.J. Andrews to Arthur Meighen, 17 Jul. 1919, NAC, Access, "Winnipeg" Justice, (Pocket 2).

33 Ibid. 
1920 who was in Winnipeg at Andrews' insistence, also wired Ottawa to urge that, "considering the conditions existing here and the opportunity for making examples" of those found in possession of radical propaganda, that prosecution under the Consolidated Orders respecting censorship had to be authorized by Ottawa. ${ }^{34}$

Meighen refused. In a letter to Ed Anderson ${ }^{35}$ - since 1906 a member of the Winnipeg law firm of Moran, Anderson and Guy, and in 1919 a prominent figure in the Committee of 1000 Meighen explained that it was not unexpected that the "citizens" would look to the Government that made the regulations to initiate and conduct prosecutions for violations of them. However, the Government had to have

regard to its proper sphere of duty and especially to the effect as a precedent and otherwise of our assuming at this stage of censorship work, duties that are constitutionally clearly provincial. ${ }^{36}$

In short, Meighen understood that the authority to act under the provisions of the War Measures Act did not apply after 11 November 1919. Such an approach was consistent with Meighen's approach to dealing with the crisis through resort to permanent legislation including amendments to the Immigration Act and the Criminal Code. ${ }^{37}$ As long as Meighen remained acting Minister of Justice, no prosecutions under the Consolidated Orders were approved.

34 E. Chambers to C.J. Doherty, 17 Jul. 1919, NAC, Access, "Winnipeg" Justice, (Pocket 1). For a discussion of Chambers career as chief press censor during the Great War and the post-war crisis see Jeff Keshen,"All the News That Was Fit to Print: Ernest J. Chambers and Information Control in Canada, 1914-1919," Canadian Historical Review, 73, 3 (1992), 313-43.

35 On Anderson see Who's Who in Canada (Toronto 1937), 371. Meighen to Ed Anderson, K.C., 18 Jul. 1919, NAC, Access, "Winnipeg” Justice, (Pocket 2).

36 Ibid.

37 F. Murray Greenwood, "The Drafting and Passage of the War Measures Act in 1914 and 1927: Object Lessons in the Need for Vigilance," in W. Wesley Pue and Barry Wright, Canadian Perspectives on Law and Society: Issues in Legal History (Ottawa 1988), 304. 
In addition to his refusal to sponsor prosecution of the strike leaders or to employ Orders in Council against radicalism, Meighen frustrated the Committee of 1000's demands for a national commission of inquiry into labour radicalism. The Committee had rejected the Robson Commission, appointed by the Province of Manitoba on 4 July 1919 to inquire into and report upon causes and effects of the General Strike, as too narrow in focus. On 7 July 1919 Edward Anderson wrote to Meighen to explain that he, Issac Pitblado, J.B Coyne, and Travers Sweatman were convinced that a national commission was required to investigate the One Big Union, the Socialist Party of Canada, the spread of Bolshevism and its connection with the Winnipeg General Strike. They believed that the focus of the Robson Commission was too narrow for "what the Dominion government has on hand is a Dominion wide matter and not local at all.",38 A.J. Andrews also wanted a national commission appointed. He told Meighen that his associates in the Committee of 1000 were "very insistent that this should be done." Andrews linked the commission of inquiry with pending criminal prosecutions of the strike leaders. In a letter to Meighen on 8 July 1919 , he noted cryptically that, if the commission was appointed, he could disclose "a source of evidence that would make it comparatively easy to proceed with our prosecutions.",39

38 Edward Anderson, K.C., to Arthur Meighen, 7 Jul. 1919, NAC, Access, "Winnipeg" Justice, (Pocket 2).

39 A.J. Andrews to Arthur Meighen, 8 Jul. 1919, NAC, Access, "Winnipeg" Justice, (Pocket 2). Andrews also lobbied Sen. Gideon Robertson, the Minister of Labour, on the matter of a commission and sought Robertson's support for the Committee's efforts in the battle against radicalism. He proposed that the Committee be given a "money grant" and, to counter the propaganda of the radicals, he recommended that the government distribute "carefully prepared sound publications and ... supplement this with a campaign of lectures throughout the country." A.J. Andrews to Sen. G.D. Robertson, 9 Jul. 1919, NAC, Access, "Winnipeg" Justice, (Pocket 2). The first suggestion appears to have been followed. In August 1920 the Department of Labour issued a supplement to the Labour Gazette entitled Information Respecting the Russian Soviet System and Its Propaganda in North America. Records of the Department of Labour, RG27, Vol. 168, File 613.04:1. 
Meighen rejected the idea of such a commission as simply a duplication of the work of the Robson Commission. The Committee of 1000 refused to accept this view. On 16 July 1919 A.L. Crossin, a prominent Winnipeg business executive and in 1919 the investment manager for the firm of Oldfield, Kirby and Gardner, wrote to Meighen on behalf of the Citizens. ${ }^{40}$ Crossin told Meighen that a commission was required

to inquire into the origin of the Bolshevistic campaign in Canada by whom promoted and financed what its objects are and the means taken to spread the propaganda and also to investigate any other revolutionary movement having any connection with this. ${ }^{41}$

Moreover, he asserted that the Winnipeg General Strike had been promoted by extremists inspired by the "Bolshevistic movement in Russia," was "financed by sources not yet made public," and was part of a "conspiracy, national, or international in character." Crossin concluded that Canada's labour organizations had been "hoodwinked" into supporting this revolutionary movement, which, "if not destroyed, will destroy us." Accordingly, "a complete exposure of the whole damnable conspiracy ... is imperative if we are to have industrial peace in Canada. No judicial trial or provincial commission can be expected to disclose the origin, extent, and purposes of this movement." ${ }^{, 42}$

In an effort to mollify the Committee, Meighen told Ed Anderson that the stream of correspondence from Winnipeg had caused him great concern, principally because "the majority of Council could not see their way clear to meet fully, the wishes of the Committee." ${ }^{, 43}$ Yet he had secured authority from Cabinet to direct Andrews to make "certain enquiries which if favourably answered,

40 On Crossin see the Winnipeg Tribune, 22 Oct. 1956.

41 A.L. Crossin to Arthur Meighen, 16 Jul. 1919, NAC, Access, "Winnipeg" Justice, (Pocket 2).

42 Ibid.

43 Arthur Meighen to Edward Anderson, 18 Jul. 1919, NAC, Access, "Winnipeg" Justice, (Pocket 2). 
will result in action that I think will be satisfactory all around.",44 On 18 July Meighen directed Andrews to consult with the provincial Attorney General and ascertain whether the province would object to the Dominion Government constituting Robson a commissioner under the Enquiries Act to engage in a general investigation of labour radicalism along the lines desired by the Citizens' Committee. Robson would execute both commissions concurrently and report to each government. Andrews was also directed to consult with Robson. There is no evidence that Andrews followed these directives from Meighen. ${ }^{45}$

Notwithstanding the Province of Manitoba's refusal to prosecute the sedition cases, and Meighen's repeated direction to Andrews that the federal Department of Justice would assume no responsibility for these prosecutions, on 22 July 1919 Andrews appeared in court ostensibly for the crown during a preliminary hearing into charges against the strike leaders before Provincial Police Magistrate R.M. Noble. ${ }^{46}$ As there is no evidence to suggest that the direction given Andrews by Meighen had been changed, or that the province had reconsidered, it is unclear for whom Andrews was appearing. Perhaps the transition required by the return of C.J. Doherty from Europe allowed Andrews some discretion and he chose to proceed notwithstanding Meighen's explicit direction not to do so. Certainly the issue of who was representing the Crown was unclear to the defendants. In 1926, A.A. Heaps, one of those arrested in 1919, told the House of Commons that

It was a mystery during the whole of that period as to who constituted the Crown. We could not find out. We were told there

44 Ibid.

45 Arthur Meighen to A.J. Andrews, 18 Jul. 1919, NAC, Access, "Winnipeg" Justice, (Pocket 2).

46 Concurrent with his activities as Provincial Police Magistrate, at the behest of A.J. Andrews, Noble had been appointed to Chair the Immigration Board which was responsible for making a decision under the revised Immigration Act on the deportation of various individuals detained because of their involvement in the labour crisis of 1919. A.J. Andrews to Arthur Meighen, 11 Jul. 1919, NAC, Access, "Winnipeg" Justice, (Pocket 1). 
were two authorities representing the Crown, one in Manitoba the other in Ottawa. ${ }^{47}$

In any event, a gruelling preliminary hearing extended to 2 August 1919, during which 118 witnesses were called and over 1600 exhibits filed. At the conclusion of the hearing, the strike leaders were committed to trial at the fall assizes of the Eastern Judicial District in November. ${ }^{48}$

By 25 July 1919 C.J. Doherty had returned to his position as federal Minister of Justice. Appointed at the outset of Borden's tenure as Prime Minister, he had had a distinguished career in law and had taught civil and international law at McGill University. He was close to the Montreal financial community, director of a variety of financial institutions, and President of the Canadian Securities Corporation. ${ }^{49}$ In 1918, Doherty had worked closely with C.H. Cahan, a Montreal lawyer retained by Borden to advise the Union government on how to deal with the danger of radicalism. When Cahan produced a report in September 1918 calling for a campaign of repression against radicalism, he and Doherty worked closely to ensure the implementation of its provisions. These included, in part, the creation of the Public Safety Branch (PBS), created by Order in Council in October 1918 with Cahan as Director. The meteoric rise of Cahan's influence in the Union government ended in January 1919 when Cahan resigned from his position of Director of Public Safety. Shortly after his resignation, the PBS was abol-

47 Debates of the House of Commons, Vol IV, 1926, col. 4014.

48 A.J. Andrews to Colonel C. Starnes, 12 Aug. 1919, NAC, Access, "Winnipeg" Justice, (Pocket 1). As would be the case in the trial, a central legal issue in the preliminary hearing was the appropriateness of Crown's evidence against the accused. The court defended the prosecution's right to introduce a wide array of evidence against the accused on the basis that the accused were "ringleaders during the strike." See D.C. Masters, The Winnipeg General Strike, 116. Masters quotes W.J. Tremeear to the effect that "Evidence is admissible of what was said or done in furtherance of the common design by a conspirator not charged, after proof of existence of the common design."

49 Robert Craig Brown and Ramsay Cook, A Nation Transformed: Canada 1896-1921 (Toronto 1974), 191. 
ished. Though Cahan succeeded in alienating Doherty by moving beyond the authority of his position as Director of Public Safety, it is clear that Doherty had been an enthusiatic advocate within the Union government of Cahan's proposals for the suppression of radicalism. $^{50}$

Not surprisingly, in Doherty, Andrews found a Minister of Justice disposed to accept his counsel on the menace of radicalism. Unlike Meighen, Doherty was ready to prosecute using the Consolidated Orders in Council approved under the War Measures Act. He told Andrews that he would prosecute as long as procedures outlined in the Orders were adhered to. ${ }^{51}$ In early August, he approved the prosecution of Jacob Miller and the publisher of Die Volkestimme. ${ }^{52}$ At the same time, Doherty and Andrews evidently corresponded on matters related to the Winnipeg strike; and in late August Andrews was invited to Ottawa to discuss the state of affairs relating to the Winnipeg prosecutions. ${ }^{53}$ By that time, Doherty had apparently secured cabinet approval to sponsor the prosecution of

50 On these developments see Gregory S. Kealey, "The Surveillance State: The Origins of Domestic Intelligence and Counter-Subversion in Canada, 1914-1921," Intelligence and National Security, 7, 3 (1992), 184-91.

51 See telegram C.J. Doherty, Minister of Justice to Colonel E.J. Chambers, 19 Jul. 1919, NAC, Access, "Winnipeg" Justice, (Pocket 1). For permission to proceed see C.J. Doherty to A.J. Andrews, 26 Jul. 1919, NAC, Access, "Winnipeg" Justice, (Pocket 2). It is noteworthy the a number of letters between Andrews and Doherty written in late July were removed from those liberated under the Freedom of Information Act. F. Murray Greenwood argues that "all concerned in 1914 [including Doherty who helped draft the bill] assumed the Act would terminate at the end of the war and the fact it could remain on the statute books was a drafting slip due to the urgency with which it was passed." See F. Murray Greenwood, "The Drafting and Passage of the War Measures Act in 1914 and 1927: Object Lessons in the Need for Vigilance,'298.

52 See Andrews to Doherty, 6 Aug. 1919 and C.J. Doherty to Andrews, 8 Aug. 1919, NAC, Access, "Winnipeg" Justice, (Pocket 1).

53 C.J. Doherty to A.J. Andrews, 19 Aug. 1919, NAC, Access, "Winnipeg" Justice, (Pocket 1). Andrews and Doherty had corresponded on these matters in late July and early Aug. 1919. The correspondence from 28 Jul. 1919 to 6 Aug. 1919 involving five pages of correspondence was removed from the file released under the Freedom of Information Act. See NAC, Access, "Winnipeg" Justice, (Pocket 2), 231. 
strike leaders. Andrews had, for all practical purposes, replaced Cahan as the Union government's principal mentor on the repression of radicalism.

The responses of Arthur Meighen and C.J. Doherty to the demands of Andrews and the Committee of 1000 provide an interesting illustration of how the state "may appear to be the 'historical subject,' but is in fact the object of processes and forces at work in society." ${ }^{, 54}$ Clearly, the principal 'subject' shaping events in the wake of the strike was a triumphant regional business elite intent on reasserting its authority and crushing its adversaries. The activities of both Meighen and Doherty thus illustrate the real, yet limited, autonomy of the Canadian state in the face of demands for action by powerful elements of civil society.

Doherty's decision to wed the resources of the federal Department of Justice to the crusade of the Committee of 1000 was clearly a triumph for Andrews and the Committee. Had Doherty not agreed to this extraordinary intervention, the trial of the strike leaders scheduled for the fall of 1919 would never have been held. The trials were the fruit of Andrews' action in laying charges against the strike leadership under the Criminal Code in June, his tenacious lobby for prosecution of the cases, and Doherty's willingness to engage the resources of the Canadian state in an extraordinary assault on labour radicalism.

The costs of the prosecution had to be readjusted upwards at least three times. In the absence of a budget approved through Parliament, funds had to be provided through an Order in Council from monies approved by Parliament under the Demobilization Act. ${ }^{55}$ This procedure had the advantage of masking the involve-

54 Ralph Miliband, "State Power and Class Interests," New Left Review, 38 (Mar.-Apr. 1983), 59.

55 On 10 Oct. 1919 cabinet approved an Order in Council whereby the sum of $\$ 35,000$ was set aside from the Demobilization Appropriation in order to make payments of the legal expenses incurred in connection with the Winnipeg General Strike. Further Orders in Council on 6 Nov. 1919, and 31 Jan. 1920, were approved for the amounts of $\$ 20,000, \$ 50,000$. A total of $\$ 105,000$ was approved through Orders in Council for such expenditures by 
ment of the federal government in an extraordinary legal manoeuvre. Still, the federal Auditor General found the procedure objectionable. On 3 February 1920 E.D. Sutherland told the Department of Justice that he could not

see that the legal, or in fact any other expenditure connected with the strike, has any relation to the purposes for which that appropriation was provided.

He noted that Section 2(a) of the Demobilization Act had as one purpose "the defence and security of Canada." Sutherland did not believe that the "suppression of strikes was contemplated under this heading, and certainly not the legal expenses arising out of such occurrences." The Auditor General suggested that Parliament be asked for a special vote to approve the expenditures, ${ }^{56}$ but his advice was dismissed. ${ }^{57}$

Access to apparently unlimited financial resources was only one advantage of the Crown in the prosecution of the cases. The Crown had the advantage of a sympathetic judge. On 26 November 1919 Mr. Justice Metcalfe of the Manitoba Court of King's Bench began to hear the trial of R.B. Russell and his co-defendants. ${ }^{58}$ The

the conclusion of the Russell trial. Later on 21 Apr. 1920 an Order in Council was approved setting aside an additional $\$ 50,000$ for the prosecution of the sedition cases. NAC, Access, "Winnipeg" Justice, (Pocket 1).

56 E.D. Sutherland, Auditor General to E.L. Newcombe, Deputy Minister of Justice, 3 Feb. 1920, NAC, Access, "Winnipeg” Justice, (Pocket 1).

57 Newcombe suggested that the expenditures were warranted as the strike conditions were "due in their conception or manifestation to war conditions." See E.L. Newcombe to E.D. Sutherland, Auditor General, 6 Feb. 1920, NAC, Access, "Winnipeg" Justice, (Pocket 1).

58 They included William Ivens, R.J. Johns, George Armstrong, W.A. Pritchard, Ald. J. Queen, R.E. Bray, and Ald. A.A. Heaps. The judge in the case, Thomas Llewellin Metcalfe, was born in Portage la Prairie in 1870. After completing his school in Portage he articled with legal firms in Portage la Prairie and Winnipeg. He was called to the Manitoba Bar in 1894. Metcalfe was a partner in a number of Winnipeg legal firms. He was appointed a members of the Dominion Statute Law Commission in 1902, the King's bench in 1909 and the Manitoba Court of Appeal in 1921. In politics Metcalfe was a Liberal. Prior to his appointment to the bench, he served the Party as a member of its provincial executive and as an effective campaigner. His health was 
appearance of the strike leaders before Metcalfe was no accident. In the summer Andrews had considered seeking a venue for the trials outside Winnipeg. However the release on bail of the strike leaders in September by Chief Justice Mathers, who resided in Portage la Prairie, ended such thinking. ${ }^{59}$ Andrews told Deputy Minister of Justice E.L. Newcombe that Mathers' position on granting bail to the accused suggested that the Crown would have "difficulty in getting in our evidence with him, much greater in any event than before either Justice Metcalfe or Justice Galt who are taking the Winnipeg assizes." 60

The Crown also had the means to give the jury list special scrutiny. When the assizes opened on 4 November 1919, Andrews turned the list over to the RNWMP with ninety-seven copies of a document he had prepared. ${ }^{61}$ Each contained a list of twenty-five questions. Andrews wanted to know the views of potential jurors with regard to the Union Government war policy, Bolshevism, the Winnipeg General Strike, the Committee of 1000, trade unions and socialism. He also wanted to know whether potential jurors were returned men and, if so, volunteers or conscripts, whether jurors were Laurier Liberals, Conservatives, Unionist or Socialists, and

destroyed by the Winnipeg General Strike trials; he died in 1922. See Winnipeg Free Press, 4 Apr. 1922 and Winnipeg Tribune, 5 Apr. 1922 and the Biographical File, T.L. Metcalfe, Archive of Western Canadian Legal History, Faculty of Law, University of Manitoba.

59 For a discussion of the events and issues associated with the granting of bail to the strike leaders see Leslie Katz, "Some Legal Consequences of the Winnipeg General Strike," Manitoba Law Journal (1970), 39-52.

60 A.J. Andrews to Honourable E.L. Newcombe, Deputy Minister of Justice, 18 Sept. 1919, NAC, Access, "Winnipeg" Justice, (Pocket 1).

61 E.P. Thompson has explained that the "scrutiny of the panel is, [an] ancient and venerable practice," E.P. Thompson, "Subduing the Jury," London Review of Books, 8, 22, 18 Dec. 1986, 13. Still, if the use of the RNWMP was a routine procedure in such investigations, it is unlikely that Starnes would have reported it to the Commissioner complete with a copy of the questionnaire. See Supt. C. Starnes to the Commissioner of the RNWMP, 5 Nov. 1919. NAC, Records of the Royal Canadian Mounted Police, RG 18, Vol. 3314, file HV-1, Vol.6, "Winnipeg General Strike and Riot" (hereafter NAC Access "Winnipeg" RCMP). 
whether they were affluent. ${ }^{62}$ Finally, he sought a recommendation from the RNWMP on the suitability of each juror.

The contest associated with the selection of the jury disclosed the difficulties of mounting a successful defence on contestable procedural and substantive aspects of the criminal law. In the process of jury selection the defence could reject a small number of jurors through peremptory challenges. For its part, the Crown possessed a virtually unlimited power to reject jurors through its ability to "stand by" a juror until all other potential jurors were considered. ${ }^{63}$ Andrews almost certainly had knowledge of the attitudes of the potential jurors on a number of themes central to the trial at hand. With this and his access to standby, the struggle over the selection of the jury was one that Andrews had every opportunity to win. Even so, the Crown's determination to limit the opportunity of the defence to challenge fundamentally altered the trial of the strike leaders. During the afternoon of Wednesday, 27 November 1919 the Crown chose to try R.B. Russell separately and hold over the trial of the others until January $1920 .^{64}$ The Crown was concerned that, if the defence exercised all the peremptory challenges at its disposal with eight defendants, the available jury panel might be exhausted before a jury was selected.

Undaunted, the defence sought to extend its number of challenges by fundamentally altering the charges facing Russell. Following the decision of the bench that the defence had only four peremptory challenges and that these had been used, defence sought unsuccessfully to have Russell tried under the amended

62 Supt. C. Starnes to the Commissioner of the RNWMP, 5 Nov. 1919. NAC "Winnipeg General Strike and Riot." A bill from the McDonald Detective Agency submitted to the Justice Department by A.J. Andrews on 5 Jan. 1920 suggests that Agency was also employed in scrutinizing the jury. See NAC, Access, "Winnipeg" Justice, (Pocket 1).

63 See E.P. Thompson, "Subduing the Jury," 12.

64 Winnipeg Evening Telegram, 27 Nov. 1919. R.B. Russell was a native of Scotland where he had received his training as a machinist. After immigrating to Canada in 1911 he settled in Winnipeg and soon became involved in the city's labour movement and the Winnipeg local of the Socialist Party of Canada. 
Criminal Code assented to 7 July 1919 and in effect since 1 October 1919. Conviction under the amended Code could mean a sentence of twenty rather than two years for Russell. Yet the threat of a longer sentence entitled the defence to greater peremptory challenges. Following rejection of the request to have Russell tried under the amended Criminal Code, the only jurors to be rejected were those "stood aside" by the Crown. In the final analysis, Andrews got his jury. It was composed entirely of farmers and rural businessmen. $^{65}$

Russell and his co-defendents had been arrested and charged for their roles in the Winnipeg General Strike. Yet, the indictment ran to twenty-seven pages and covered events dating back to the meeting in the Majestic Theatre in Winnipeg in the winter of 1918, through to the end of the Winnipeg General Strike in June 1919. In the indictment, Russell and the others were charged with six counts of seditious conspiracy and one count of being a public nuisance. The central thrust of the indictment was that the Strike was planned as "a step in a revolution against the constituted form of government in Canada." ${ }^{, 66}$ Defence counsels' demand that the indictment be quashed because it did not specify on what basis or because of what acts and words Russell and his co-conspirators should be found guilty of seditious conspiracy was rejected by Metcalfe. ${ }^{67}$

The indictment defined the terrain on which the Crown intended to mount its ideological assault on labour radicalism as sedition.

65 Russell's fate rested with farmers Edward Heney and Theo Nugets from Sanford, T.W. Smith from Emerson, William Hassett from St. Francois Xavier, Roy Tolton from Otterburne, Albert A. Anderson from East Selkirk, Joseph Frechette from St. Pierre, D.H. Pritchard from Carmen, William Heale from Teulon; and William McClymont a merchant from Hazelridge, Harl Woodhead a merchant from Morris, and C.T. Fisher a manager from Norwood. Winnipeg Evening Tribune, 24 Dec. 1919.

66 Bill of Indictment, King vs Russell (1919). PAM, GR 950, Attorney General's Records, Central Registry. See also the indexed copy of the indictment in the Pitblado Papers, Scrapbook Winnipeg General Strike Trials, PAM, MG, C 64, Box 4. For a summary of the indictment see D.C. Masters, The Winnipeg General Strike, 114.

67 Winnipeg Evening Telegram, 19 Nov. 1919. 
Through it, the Committee of 1000's view of the 1919 labour revolt was formally embraced by the state as a basis for the criminal prosecution and punishment of the strike leadership. The labour revolt of 1919 was effectively transformed by the Crown into a criminal venture. Yet, the trials of Russell and the other strike leaders were not about bringing criminals to justice. They were ideological events designed to mobilize consent for the established order while constructing strict limitations on the legality of any criticism of the state and on demands for fundamental change in relations of production. ${ }^{68}$

A central issue in the trial concerned how one defined sedition. The Criminal Code provided some guidance. Subsection one of Section 132 of the Code, prior to amendment in 1919, stated that seditious words were "words expressive of a seditious intent." Subsection three asserted that a seditious conspiracy was "an agreement between two or more persons to carry into execution a seditious intention." ${ }^{, 69}$ Section 134 set out that everyone was "guilty of an indictable offence and liable to two years imprisonment who speaks seditious words, or publishes any seditious libel, or is a party to any seditious conspiracy." ${ }^{, 70}$ In efforts to define the law, Andrews explained that the accused were not on trial for what they said, or for what they intended, but for what "would ... be the natural result of such words." The law presumed that Russell intended the natural consequences of his actions or words. Moreover, it was irrelevant whether his words did create public disorder.

68 The legal adventures associated with the Winnipeg General Strike illustrate Richard F. Devlin's comment that "Law is incorrigibly subjective. Indeed, the manipulation of legality is one of the most important techniques employed by the capitalist state in its strategy of absorbing incipient conflict and eradicating dissent in such a way as to preserve the status quo." See Richard F. Devlin, "Laws's Centaurs: An Inquiry Into the Nature and Relations of Law, State, and Violence," Osgoode Hall Law Journal, 27, 2 (Summer 1989), 247.

69 Crown Counsel's (Andrews) Address to the Jury (hereafter Crown Counsel), 23 Dec. 1919, 9. PAM MG 10 A 14-2 54.

70 Winnipeg Evening Telegram, 20 Nov. 1919. 
In fact, Andrews acknowledged, they had not. ${ }^{71}$ It would be necessary only "for the Crown to prove a combination, agreement or conspiracy, to bring about, to carry into execution ... a seditious intention. A plot against the State.",72

But, what constituted a seditious intention? Andrews proposed to employ the definition suggested by British jurist, Mr. Justice Steven, that

a seditious intention is an intention to bring into hatred and contempt or to excite dissatisfaction against the person of His Majesty, or the government and constitution of the United Kingdom as by law established, or either the houses of parliament, or the administration of justice; ... [or], to excite His Majesty's subjects to attempt otherwise than by lawful means or to raise discontent and disaffection amongst His Majesty's subjects in order to promote feelings of ill will and hostility between different classes of such subjects. ${ }^{73}$

The definition proposed by Andrews, with some minor alterations, had been contained in the proposed 1892 Criminal Code but had been deleted during debates on the proposed Code because of opposition in Parliament. ${ }^{74}$ William Mulock had opposed inclusion of the definition. He argued prophetically that such a definition would intrude into controversies better left out of the courts. In particular, he had in mind "controversies between labour and capital." ${ }^{, 75}$ Mulock believed that inclusion of the proposed definition would be followed by further amendments which, eventually, would end freedom of speech. He warned Justice Minister John Thompson that

71 Crown Counsel, 23 Dec. 1919, 5.

72 Ibid.

73 Debates of the House of Commons, Vol. IV, 1919, 3289.

74 Desmond H. Brown, "Parliamentary Magic: Sir John Thompson and the Enactment of the Criminal Code," Journal of Canadian Studies, 27, 4 (1993), 30-1.

75 Debates of the House of Commons, XXXV, 1892, col. 2837. 
in a little time you will be clothing your officers with power to prevent public meetings ... The whole history of the institutions of the mother land warrants us in concluding that the greatest safety lies in freedom of discussion. A British mob allows its ill will to pass off by using strong language, while in other countries, where freedom of discussion is prohibited, this ill-will takes the form of deeds of violence and causes the formation of secret societies. ${ }^{76}$

Mulock concluded by asserting that he would "oppose anything which will prevent a man from expressing his views in regard to any matter against the state or in the state." definition from the revised Criminal Code of 1892 left discretion with the bench to exercise a quasi-legislative authority to define sedition, while prosecuting counsel such as Andrews gained considerable latitude in making their case to a jury. ${ }^{78}$

In the final analysis, then, how the state chose to define sedition was a political matter of the first order for it bore directly on the juridical nature of Canadian citizenship and the relationship between the governed and the government. Given the nature of the indictment and the undefined legal character of seditious intent, Andrews' role in the courtroom was a profoundly political one. In fact, Andrews had justified the prosecution to Meighen and Doherty as an essential act of state repression in the struggle against labour radicalism. It followed that the trial was not a typical criminal prosecution, but an ideological struggle designed to defend the status quo ante, to outlaw the One Big Union, to suppress criticism of the state, and to punish advocates of radical social and economic change. For Andrews, the sedition trials provided an opportunity to advance a construction of seditious conspiracy that resonated with what he almost certainly knew were the preconcep-

$76 \quad$ Ibid., col. 2837.

77 Ibid., col. 2837.

78 Desmond H. Brown, "Parliamentary Magic: Sir John Thompson and the Enactment of the Criminal Code,"38. For a discussion of the law of sedition as it applied to the Russell case see Desmond H. Brown, "The Craftsmanship of Bias: Sedition and the Winnipeg General Strike," Manitoba Law Journal, 14 (1984), 1-33. 
tions held by the jury that the strike was the project of disloyal, unpatriotic, undemocratic "Reds" consumed with a determination to impose a Soviet style dictatorship on Canada.

R.B. Russell's trial extended from late November 1919 until the end of December. Throughout, Andrews contended that evidence of Russell's seditious intent was ubiquitous. For example, while none of the resolutions adopted during the Walker Theatre meeting in December 1918 were seditious, Andrews contended that, if the jury "pierced the thin veil of deception" it would see a meeting full of seditious intent. Moreover, those at the meeting had "endeavoured to establish the fact that there was a class struggle." "It was clear to Andrews that the timing of the Walker Theatre meeting demonstrated seditious intent. The organizers of the event had chosen the most effective time to promote discontent and disaffection. Andrews explained to the jury that "some of you are farmers and you know there is a law in this country which compels you as a precautionary measure to have a certain number of men present when you light a fire on the prairie.",80

Russell's association with the Socialist Party of Canada (SPC) provided further evidence of his guilt. ${ }^{81}$ Andrews alleged that the Party advocated the abolition of national sentiment and promoted allegiance only to class. Such a doctrine was the moral equivalent of that embraced by deserters and opponents of conscription. Andrews also charged that the SPC was undemocratic. It taught that the political actions of the working class were not constrained by the bounds of parliamentary rule. Any political action was justified if it was "action taken by the slave class against the master class to obtain control of the powers of the state." 82 In Andrews' view, such

79 Winnipeg Evening Telegram, 28 Nov. 1919.

80 Ibid, 33.

81 For an astute analysis of the program and intentions of the Socialist Party of Canada in 1919 see Gerald Friesen, "'Yours in Revolt": The Socialist Party of Canada and the Western Canadian Labour Movement," Labour/Le Travailler, 1 (1976).

82 Crown Counsel, 38. 
claims warranted prosecution for seditious conspiracy. As Andrews explained, it was

not a crime for Mr. Russell to get up and say that he thinks the Russian government is a fine government, but he must not carry it to the limit of getting people to hate our form of government, he must not excite revolt; he must not excite discontent. ${ }^{83}$

To underscore the misguided nature of Russell's alleged views, Andrews asserted that there was no master class or slave class in this country. Conditions existed which provided a "free opportunity for every man to rise." Andrews prayed that the time would never come when under the dictatorship of the proletariat all were reduced to one level. ${ }^{84}$ Just as there was no master class or slave class in the country, the notion that the state was a tool of a "bourgeois" ruling class was a simple fabrication and seditious because it was designed to cause disaffection between the people and their government.

In addition to promoting disaffection within the state, the assertions of class rule denigrated the enormous sacrifice made by those who went to war for Canada. Andrews invited the jury to consider this from a very personal point of view:

Some of your boys went to war. Did they know they were offering their lives to extend the profits of capitalists. Don't you think that they went into this war for a principle. And haven't you given your money, and have not some of our friends given their lives for this principle. ${ }^{85}$

Yet, what had Russell and his associates done? They had provoked the Strike and pointed guns at the head of the community to get their way. ${ }^{86}$

83 Ibid., 50.

84 Ibid., 31.

85 Ibid., 26.

86 Ibid., 54. 
Efforts by the defence to mount an ideological response to the prosecution's withering month long denunciation of Russell in which the Crown submitted over 1,700 documents as evidence against the accused were frustrated by the Bench. ${ }^{87}$ Latitude that Justice Metcalfe openly granted to the prosecution was denied the defence. Metcalfe refused to allow the admission of evidence concerning the role of the Committee of 1000 in the Strike. For example he refused defence counsel permission to enter as evidence a copy of the Winnipeg Citizen. Defence wished to show that the Committee had published falsehoods and had prejudiced the cause of labour. ${ }^{88}$ Through such nefarious activities, contended the defence, the leaders of the Citizens' Committee had engaged in a conspiracy to crush the labour movement. Metcalfe told the court that the Committee had nothing to do with the trial and ruled that the paper not be introduced as evidence.

Lead defence counsel Robert Cassidy, K.C., also contended that government policy in regard to the strike had been directed by the Committee composed of "the bankers, all the loan company managers, all the money class of Winnipeg." ${ }^{, 89}$ Moreover, Russell's trial was " not an ordinary court procedure but one conducted by a vigilance committee. ${ }^{, 90}$ Cassidy denied the existence of a conspiracy and asserted that the strike was a conflict over the principle of collective bargaining.

Defence counsel also responded to the prosecution's case with a defence rooted in legal process and procedure. For example, Cassidy opposed the admissibility of much of the Crown's evidence as not applicable to the charges against Russell. He argued that evidence related to the activities and program of the Socialist Party

87 Canadian Annual Review, 1919, 480.

88 Winnipeg Evening Tribune, 12 Dec. 1919.

89 Winnipeg Evening Telegram, 17 Dec. 1919. Robert Cassidy K.C. emigrated to Canada from his native Ireland as a young man and practiced law for many years in Victoria and Vancouver. In his distinguished career he appeared in every Court in B.C., the Supreme Court of Canada and the Judicial Committee of the Privy Council. See his obituary in The Advocate, 5 (1947), 99.

90 Winnipeg Evening Tribune, 22 Dec. 1919 
of Canada and the One Big Union was not legal evidence of seditious intent. As he told the court, "if we are to be held responsible for the statements of every organization, or of every individual who was ever a member of the Socialist party, we might just as well send the accused to jail right away." admitted the Crown's evidence conditional upon Andrews demonstrating the complicity of Russell.

The defence was more successful in advancing its contention that the introduction against Russell of Orders in Council which prohibited literature found in his possession was improper. They argued that the War Measures Act and the Orders in Council arising from it were in force only during the war. ${ }^{92}$ Defence counsel also noted that the Mathers Commission had recommended the rescinding of Orders in Council affecting freedom of the press and the freedom of speech. Metcalfe denied the admission into evidence of the recommendations of the Mathers Commission, yet he did acknowledge with regard to Orders in Council that the defence had raised a very substantive point that he was reluctant to rule on without consultation. ${ }^{93}$

At the conclusion of the trial, Judge Metcalfe's charge to the jury lasted three hours and twenty minutes. A number of legal scholars have agreed with W.H. Trueman's assessment that Metcalfe's charge was based on "a complete conviction of Russell's guilt.",94 Assessing Metcalfe's performance, Desmond Brown concluded that

it was perhaps his skilful manipulation of cases, to arrive at a pernicious definition of conspiracy, that was repugnant to the provisions of the Criminal Code, which best displayed his juristic

91 Winnipeg Evening Telegram, 6 Dec. 1919.

92 Ibid., 12 Dec. 1919.

93 F. Murray Greenwood argues that the Borden government had given assurances in 1914 that the use of the authorities provided in War Measures Act would be used only during the war. See F. Murray Greenwood, "The Drafting and passage of the War Measures Act in 1914 and 1927: Object Lessons in the Need for Vigilance," 291-307. 
talents. It is a fact that the jury could have found Russell not guilty, but Mr. Justice Metcalfe was a judicial craftsman of the first order, and the jury took his direction and pronounced the verdict he so obviously desired. ${ }^{95}$

Russell was convicted on all counts and sentenced to two years in prison. Efforts to appeal the conviction on the legality of the indictment, the selection of the jury, the trial judge's rulings on the admissibility of evidence, and the content of his submission to the jury were unsuccessful. ${ }^{96}$

Andrews had begun preparations for the trial of the remaining seven strike leaders immediately after the Russell trial. He told Doherty that there were 250 names on the jury list and that he was taking steps to obtain the list and to make arrangements to secure information about potential jurors. ${ }^{97}$ The McDonald Detective Agency was retained for this purpose. ${ }^{98}$ When the trial began at the end of January, Andrews faced a jury composed entirely of farmers from rural Manitoba. ${ }^{99}$ In order to get the 12 jurors, Andrews had stood aside 31 others.

95 Ibid., 32-3.

96 Report to the Commissioner, RNWMP, 19 Jan. 1920, NAC, Access, "Winnipeg" RCMP. Because the Manitoba Appeal court was unanimous in its ruling Russell could not appeal his conviction to the Supreme Court of Canada. He was however able to appeal to the Judicial Committee of the Privy Council. The JCPC refused to hear his appeal. See Esau et al. For an assessment of the findings of the Appeal Court see Leslie Katz, 44.

97 Andrews to Doherty 25 Dec. 1919, NAC, Access, "Winnipeg" Justice, (Pocket 1).

98 Winnipeg Free Press, 29 Jan. 1920. In the course of selecting the jury 110 jurymen were called and considered. Of these 17 were peremptorily challenged by the defence; 41 stood aside on grounds admitted by both the defence and crown; 7 were tried and found unfit; 1 ruled unfit by the judge. On the Macdonald Detective Agency see bill for service, 5 Jan. 1920), NAC, Access, "Winnipeg" Justice, Pocket 2.

99 The jury was composed of D. Bruce, Carman; G.C. Glenny, St. Marks; A.H. Quick, Emerson; George Morrison, J.M. Henderson, Hazelridge; James Jack, James Kirkpatrick, Ridgeville; John Stephens, Hazelridge; A. Davidson, Sperling; Herman Johnson, Lundar; Thos. Spence, Greenridge; and Alex Sinclair, Tyndall. Winnipeg Free Press, 25 Jan. 1920. 
On 20 January 1920 the case against William Ivens, R.E. Bray, W.A. Pritchard, John Queen, A.A. Heaps, George Armstrong, and R.J. Johns began with Justice Metcalfe presiding. The evidence presented by the Crown against the accused was similar to that advanced in the Russell case. A. J. Andrews sought to implicate the accused in a seditious conspiracy through their participation in the principal events of the period beginning with the Walker Theatre meeting in December 1918 and through their association with the One Big Union, The Socialist Party of Canada and the Winnipeg General Strike. He told the jury that R.B. Russell had been convicted on essentially the same evidence presented by the Crown against Ivens and the others.

The defendants understood their prosecution to be a political struggle. From the outset they challenged the legitimacy of the proceedings. The defence alleged that the Sheriff or his officers had improperly allowed Counsel for the Crown to examine the jury list before it had been returned to the Court; that the Crown had interfered with the jury; that Counsel for the Crown was not fit to prosecute because of their personal involvement in the strike; that Justice Metcalfe was biased and therefore unfit to preside; that the Indictment was inadequate; and, that the accused could not get a fair trial owing to the publicity given the case of R.B. Russell. Metcalfe dismissed all defence motions other than that dealing with the challenge to the array of jurors. In the proceedings that followed, Deputy Sheriff Pyniger told the court that an order had been presented signed by Justice Galt of the Court of Appeal ordering him to give the Counsel for the Crown a copy of the Jury list. He had done so and, at the same time, had supplied a copy to the counsel for the Defence. Masters reports that defence counsel McMurray "denied that he had heard of Mr. Justice Galt's order." ${ }^{100}$ In the end a verdict was returned completely exonerating the Sheriff of any misconduct with regard to the jury list. 
The defendants countered the Crown's political prosecution with an unconventional defence. They called no witnesses, sought to discredit Crown witnesses as paid informants, and responded to the prosecution with lengthy refutations of the Crown's case. The insistence of Queen, Ivens, Pritchard, and Heaps that they speak for themselves reflected an understanding among the defendants that they, not counsel, were better able to advance the kind of radical discourse required to counter the ideological assault from the Crown. Each sought to situate the labour revolt of 1919 on the terrain of legitimate political and social struggle. In long addresses the defendants with their lawyers, W.H. Trueman and E.J. McMurray, contested the legitimacy of the proceedings, defended the General Strike and the One Big Union, and advocated the cause of labour radicalism.

John Queen told the court that the Citizen's Committee, not the Strike Committee, had usurped the authority of the City Council during the strike. ${ }^{101}$ Queen believed that his prosecution was politically inspired. A.J. Andrews had a personal interest in his conviction for it would mean his removal from City Council. Queen believed that the Crown was attempting to introduce a reign of terror in Canada. The nocturnal raids of the homes of workers across the country to secure materials that could be "bought at bookstores" was designed to "give the impression to the people of Canada that it was a terrible crime to have this literature and they must use stern measures to get the evidence." ${ }^{\prime 102} \mathrm{He}$ sought the jury's protection from the "unholy hands" of A.J. Andrews who had instigated what Queen viewed as judicial persecution.

William Ivens framed his address in the idiom of the Social Gospel with himself as a "liberator." He invited the jury to consider the fact that "emancipators always have been thrown in jail." The real criminals were the "profiteer who became rich out of blood and tears and who wraps himself in the flag and becomes a

101 Winnipeg Evening Tribune, 18 Mar. 1920.

102 Ibid., 19 Mar. 1920 
patrioteer." He charged that his arrest and the arrests of the other defendents had been designed simply to break the strike and "there had to be a case patched up afterward.",103

In his address to the jury, W.H. Trueman sought to situate the labour revolt of 1919 squarely within the tradition of legitimate British radicalism and to portray it as a campaign for substantive rights of citizenship. To legitimize Canadian radicalism, Trueman invoked the prestige of the British Labour Party. He quoted extensively from an article by Arthur Henderson, Secretary of the Labour Party, on the post-war industrial unrest. Henderson had traced the roots of unrest, not to the War, but to "an insurgent spirit" which was "in essence a moral struggle to attain to the complete development and fullness of human life." The workers had fought oppression abroad and were determined to reject an equally unacceptable economic and industrial oppression at home. ${ }^{104}$ Trueman contended that Henderson's analysis of the British scene applied equally well to Canada.

E.J. McMurray told the jury that the trial deserved "to rank with the trials 150 years ago in England when men stood up in court and fought a despotic government." He attacked the assault on the strike leadership through the amendments to the Immigration Act, the Criminal Code, and the judicial process, and contended that the trial amounted to, a "fight for freedom of speech, freedom of the press and the right of labour to organize." 105 In McMurray's view the trial was simply a concerted effort to "get" leaders of the workers who had been making a determined fight for labour's rights. $^{106}$

Prichard's address was regarded by observers as a masterpiece. In it he condemned the continued imposition of the War Measures Act as abhorrent for "the power given the governor-in-council by

103 Ibid.

104 The Right Hon. Arthur Henderson,"The Industrial Unrest: A New Policy Required," 361-369, The Contemporary Review, CXV (Jan. - Jun. 1919).

105 Winnipeg Evening Tribune, 20 Mar. 1920.

106 Ibid., 22 Mar. 1920 
this act made him practically an autocrat." He contended that every British subject had the right to hold or express any theory of government provided he did so without violence or malicious purpose. ${ }^{107}$ Pritchard believed that history would vindicate his position. As he told the jury: "this is not so much a matter of Pritchard's liberty as a matter of history. History, I am sure will vindicate us."

Pritchard also defended the One Big Union. It was the only way for the skilled worker to protect himself from low wages and unemployment. The formation of the trust in modern business had made the same sort of organization necessary among workers. Moreover, the machines of modern industry had broken down the workers' craft divisions and the workers themselves had to break down their own craft lines and organize together to meet the new conditions they faced. Pritchard condemned the prosecution as "the most damnable piece of infamy that ever has been perpetuated in any court of justice in the British Empire." ${ }^{, 108}$ He told the jury that "you can't kill theories with a club and you can't blow theories into oblivion with machine guns."

The political turn of the addresses by Prichard and the others concerned Andrews and the RNWMP. Pritchard's address, noted a RNWMP report, caused excited comment throughout Winnipeg. It was " a masterful defiance of law, Court, Judge and Jury, and quite at variance with the utterances of the others." The Police feared that Prichard's acquittal would have a dramatic effect on the minds of the workers. It would signal that he was "above the law." Agent 65 suggested to his superiors that "it would be a good idea to prohibit Sunday meetings in theatres or Public Halls for a time or meetings of any kind?",109

On 27 March 1920 Ivens, Pritchard, Johns, Queen, and Armstrong were found guilty on all counts. R.E. Bray was found guilty of being a Common Nuisance and A.A. Heaps was acquitted of all

107 Ibid., 24 Mar. 1920.

108 Ibid., 23 Mar. 1920

109 Report from Agent 63, 24 Mar. 1920, NAC, Access, "Winnipeg" RCMP. 
charges. As well, a strong recommendation of mercy accompanied the verdict in each case. On the morning of 6 April 1920 Ivens, Johns, Pritchard, Queen and Armstrong were sentenced to one year each on the first six counts of seditious conspiracy and six months each on the seventh. The sentences were to run concurrently. R.E. Bray was sentenced to six months at hard labour on the charge of common nuisance. In passing sentence, Metcalfe noted that he was taking into consideration the recommendation for mercy made by the jury. ${ }^{110}$

A.J. Andrews believed that the prosecutions had been required to justify the suppression of the Winnipeg General strike, to mobilize consent for the established order, and to limit legal criticism of the state. While convictions were secured, Andrews could claim only limited success for his strategy of employing the courts and the criminal law to buttress the social order. ${ }^{111}$ In the face of a vigorous prosecution and before an unsympathetic judge, Russell and his co-defendants contested their prosecution through substantive refutations of the Crown's case and procedural strategies inherent in the law. Across the country workers dismissed the prosecution as simply state repression disguised. In April, following the trials, Andrews acknowledged to C.J. Doherty that it was "questionable if we could secure the conviction of these people by other juries." 112

The Winnipeg General Strike reflected a broadly based rejection of pre-war relations of power and authority. Not surprisingly, the tide of post-war radicalism did not subside with the state suppres-

110 RCMP Report, 7 Apr. 1920, NAC, Access, “Winnipeg” RCMP.

111 Barry Wright has shown how "The imposition of emergency executive enabling legislation on a permanent basis (the War Measures Act), the widened definitions of unlawful assembly and seditious activity, as well as aliens and the summary deportation of aliens (amendments passed during the Winnipeg General Strike followed by sections 41 and 42 of the Immigration Act and section 98 of the Criminal Code) all had precedents in the Upper Canadian measures. Barry Wright, "Sedition in Upper Canada: Contested Legality," Labour/Le Travail, 29 (Spring 1992), 7-57.

112 A.J. Andrews to C.J. Doherty, 29 Mar. 1920, NAC, Access, "Winnipeg" Justice, (Pocket 1). 
sion of the strike. During the summer of 1919, Andrews and the Citizens' Committee remained convinced that the intervention of the state against the strike had not removed the threat of social disorder. Determined to ensure continuing state action to subdue agents of disorder, Andrews and the Committee of 1000 constituted themselves as a kind of vanguard of reaction against continuing currents of opposition to the status quo. Led by A.J. Andrews, members of the Committee mobilized the authority and resources of the federal Department of Justice in legal and ideological assaults on labour radicalism designed to discredit and disperse proponents of radicalism in Winnipeg and elsewhere and to restore the legitimacy of the existing order. Claims for a substantive citizenship rooted in the ideological legacy of the Great War were dismissed. Post-war radicalism was condemned as a species of Bolshevism and the workers' revolt of 1919 was condemned as a criminal enterprise. Yet, the legal and ideological ascendency of the Citizens and their allies in the state was far from absolute. Rather than produce mass adhesion to the established order, the assault on radicalism generated working-class dissent and antagonism. Contrary to the general portrayal of the strike's aftermath as a period of abject defeat for labour, the response of workers to the offensive against radicalism engineered by the Citizens was one of struggle and resistance. In doing so, workers, in Winnipeg and elsewhere, came to a better understanding of the strategies, resources, and will required in the complex and ineluctable struggle in which they were involved.

The author would like to thank Gerhard Ens, James Naylor, Morris Mott and the anonymous readers of left history for critical assessments of an earlier draft of this paper. He would also like to acknowledge Alvin Esau's generous invitation to research the Department of Justice files secured through the Freedom of Information Act by the Legal Research Institute at the University of Manitoba. This paper is based largely on that research. 